\title{
On Sustainable Property Development - The Case of Budapest
}

\author{
Tom Kauko*
}

Department of Geography, NTNU, Norway

\begin{abstract}
Sustainable development is conceptualised along three dimensions: environmental-ecologic, social-cultural and economic-financial. In this study sustainability is defined in terms of three specific evaluation criteria: quality, affordability and diversity. Evidence from Budapest suggests that quality varies (new versus old in particular), affordability is low and diversity, while high overall, is very limited within new developments. While the situation for property developments are weak, fortunately, amid an otherwise bleak situation, prospects for a minority of innovative and adaptable developers who operate in market niches are encouraging as these foster a relatively sustainable development in terms of one or more of the three dimensions. Moreover, in the longer term particular opportunities for sustainable development are likely to open as the maintenance of the new stock is more affordable and of better quality than the old stock.
\end{abstract}

Keywords: Budapest, Hungary, evaluation, property development, sustainability.

\section{INTRODUCTION}

The Hungarian type of gated communities (residential park, lakópark, lakókert) is currently a popular category of property developments. This type of residential project is designed for an up-market modern condominium or singlefamily home with security systems, high-level maintenance and other services included in the housing package. (Some of the services might also be available for the public.) One such project, Marina Part in Angyalföld (Budapest district XIII ${ }^{1}$ ) near Duna Plaza shopping mall is the first large Danube waterfront project, comprising exclusive flats for well-to-do buyers. This is a citadel surrounded by water and fences. It is built based on principles that investors, developers and architects thought were going to be profitable before the financial crisis kicked in. This residential development comprises several almost identical high-rise tower-blocks with ornamental walls and other decorations. It also features a private marina for boats, green areas for children, a trail along the river and a centralised security system. The design creates the impression that this development is completely isolated from its surroundings, socially and physically. Most flats appear to be empty if turned on lights after nine in the evening is a valid indicator.

Another type of lakópark on Vaskapu Street in district IX close to the waterfront and Boráros tér nodal point is a more modest proposition. It is meant for the urban middle-class and small households; partly for foreign investors too. It is not too flashy, but nonetheless a guarded area situated

*Address correspondence to this author at the Department of Geography, NTNU, NO-7491, Trondheim, Norway; Tel: +47 73591919;

Fax: +47 73591878; E-mail: tom.kauko@svt.ntnu.no

${ }^{1}$ Budapest consists of 23 administrative districts, each with local government authority over their territories, and a metropolitan municipality with powers to address cross-district issues but without hierarchical powers over the 23 districts. around a cul-de-sac. At first look this project seems spot on: it fits well with the surroundings and makes an integrated part of the streetscape. However, at closer inspection the quality of the finishing is found shabby: the skin of the building is not real brick but fake 'concrete-brick', although this is noticeable only to the trained eye.

These kinds of vignettes based on field work around new housing developments in Budapest illustrate how difficult it is to manage the provision of the post-socialist urban landscape in a responsible way, in a situation where already the starting point was problematic because of a lack of funds and often political will, and now the financial crisis has magnified the difficulties due to low demand and sporadic development activity. After the transition over two decades ago, Hungary has experienced enormous and rapid qualitative changes in the built environment. This context has changed from central planning to neo-liberalism some twenty years ago, and now is changing towards sustainable development aspirations much with aims to join a western European tradition of decision-making concerning the built environment. (This agenda is explained in the next section.) That the circumstances offer less reason for optimism in Hungary than in Europe on average is obviously a constraining parameter, given that in some western countries sustainability or green features are already more institutionalised than here. The most characteristic general feature of the Hungarian urban real estate context is that of perennial instability - with greater frequency and magnitudes than in western countries - caused by dramatic turns in economic and political fortunes.

Kulcsar and Domokos [1] discuss more general tendencies of post-socialist urban growth and (following Harvey Molotch, 1976) place them into a Growth Machine perspective usually applied in the US urban context. They find that the general logic of post-socialist urban growth involves elite coalitions, self-interested promotion of growth and unequal benefits of this growth. However, the local 
elites during post-socialism are found to be political as opposed to economic elites, which is a main difference to the US based theory model ${ }^{2}$. These authors make several observations about how the property development in Hungary has occurred since the transition. Kulcsar and Domokos argue that unlike other CEE countries, in Hungary the transformation only consolidated the previous structure, as the elites managed to transform their previous economic power in the new system to obtain capital. Another feature of the Hungarian case is the absence of NGOs. In such circumstances inside info could at the start be used to get an elite position, but once these local elites had established themselves it was difficult for newcomers to achieve foothold there. This mechanism applied for different kinds of property developments such as expensive housing development, land speculation connected to these residential areas through manipulation of zoning and building of shopping centres as symbols of western style consumption.

The research problem can thus be formulated as follows: why is it important to improve the real estate stock in the post-socialist context and if so, then how can a sustainable development approach constitute a feasible goal [2]? The present study is based on expert interviews. While some relevant issues such as socially responsible investment were left out, the coverage goes beyond mere environmental and ecological considerations that so often are equated with sustainability. The evidence suggests that, while a number of sustainability issues have been tackled well within certain economic and environmental dimensions, two (possibly three) unsustainable counter forces prevail. One unfavorable issue concerns the poor locations chosen for peripheral or suburban developments - this mostly refers to land use and neighbourhood amenities. Another concerns the poor timing of the investments together with local market friction caused by administrative and political parameters - this mostly links with the price setting of the new stock. The third one would be the problem of too narrow range of property products, but this issue is difficult to confirm as it links to several diversity aspects such as property price-levels, land-uses and amenities.

\section{EVALUATION CRITERIA FOR SUSTAINABLE URBAN PROPERTY DEVELOPMENTS}

The Western European experience of globalised problems of urbanisation is often taken as starting point for studies on urban sustainability (the topic of this section). On the other hand, the post-socialist transition has caused a somewhat different set of urban problems when the physical environment has changed slower than the socio-economic development with negative consequences, such as the majority of urban inhabitants at present living in low quality housing and residential environments, in particular housing estates; or urban sprawl (the topic of next section). According to Stanilov [2], however, we have "an opportunity to solve two problems with one solution" insofar as tackling both global sustainability problems and post-socialist problems of unsustainability is achievable using a generic approach to urban sustainable development. The fact is that, in West aims to achieve urban sustainability are increasing in importance, despite the fact that the buildings tend to be

${ }^{2}$ Obviously there is overlap between economic and political elites. more sustainable there than in the post-socialist/CEE urban context. We can furthermore observe that in post-socialist circumstances the goal is not only to catch up with current western standards, but also to use the same 'globalized plans' for improving the sustainability when upgrading the stock. Thus the regional argument in relation to post-socialist problems and the global argument in relation to sustainable development can be seen as a conjunction of two aspects: on one hand, global challenges in relation to the use of resources; on the other hand, challenges related to the postsocialist urban transition.

As shown in Fig. (1), sustainability is commonly conceptualized as constituting three overlapping basic dimensions: environmental-ecologic, social-cultural, and economic-financial. The first of them refers to 'green' buildings/developments, and is considered the traditional form of sustainability criteria related to pollution, energy efficiency and renewables. The second is a new category that is more difficult to define exhaustedly, but includes in general a variety of qualitative issues related to human activity. The last of the three dimensions in turn refers basically to economic indicators, but with the difference to mere cost-benefit analysis being the long, optimally intergenerational, perspective of identifying the monetary quantities at stake. In many cases also other dimensions are used (functionality, governance etc.), but in most of these cases the definitions boil down to one or more of the three basic dimensions. Various definitions of these concepts exist [3-5].

Fig. (1) shows the different dimensions along which sustainability is conceptualised and to some extent measured. This figure merely shows how the three dimensions may overlap both in theory and practice. Moreover, empirical findings are often surprising. For instance, Wagner and colleagues [6] show that the building performance of low energy offices does not contradict the improved social sustainability gains of increased occupant satisfaction - or even the economic sustainability that indirectly results from increased worker productivity. In this particular case, a survey of occupants of 16 buildings in Germany suggests energy efficiency (thus the 'green' dimension) and occupier satisfaction (thus social and economic dimensions) work in the same direction (although there is a good chance that occupants self-select). In fact, it is sometimes argued that sustainability can only be evaluated to the extent two of these dimensions overlap [7]. Accessibility (i.e. of households and businesses to shops, schools, public transit, health services and so forth) is a good example of an expected sustainability effect which concerns at least two of the three dimensions; accessibility generates economic benefits through time-saving and environmental benefits through reduction in pollution caused by slow car traffic, but on the other hand the same accessibility improvement can also be unsustainable socially if this involves forced location choices by a government who forces the residents or firms to relocate [8].

Using Fig. (1) as a backdrop, a set of Twelve broad issues surrounding the sustainability of general urban sustainability as well as real estate applications are selected. This is done in a rather ad hoc way. These are listed below, starting from the most localised to the widest scale, based on 


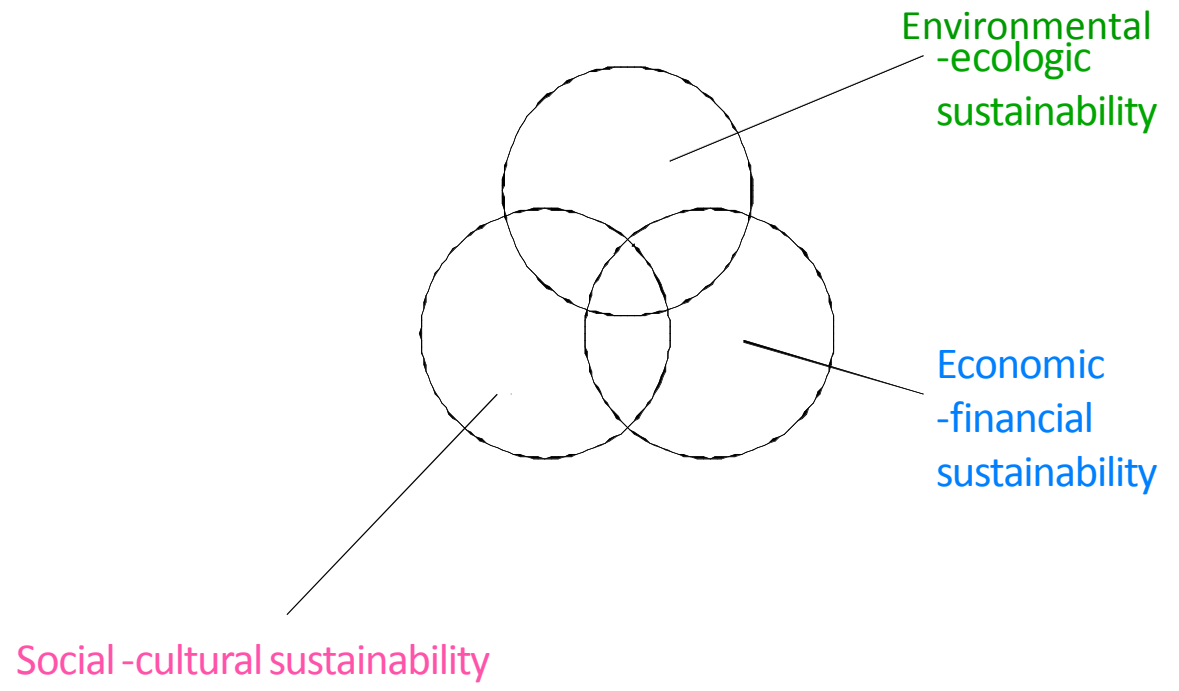

Fig. (1). The theoretical starting point.

various literatures (urban sustainability, sustainable real estate, in particular) as well as anecdotal evidence. Furthermore, Fig. (1) shows that the dimensions might overlap.

1. Energy efficiency in buildings (during their life cycles).

2. Use of renewable energy in buildings (during their life cycles).

3. Pollution control in building (during their life cycles).

4. The quality of property products.

5. The affordability of property products.

6. The diversity of property products.

7. The optimal density for a block or neighbourhood.

8. Public transportation availability.

9. Traffic pollution.

10. Social cohesion in the neighbourhood or city

11. Communicativeness in local or regional planning (governance transparency)

12. Innovativeness of the region (economic sustainability, including financial transparency of corporations, and favouring local products and labour)

Moreover, the socioeconomic and socio-cultural sides of urban property development often also involve considerations of what an ideal location should be rather than only taking the buildings into account. This is seen especially clearly within an urban renewal context [9-11]. First, economic sustainability (i.e. the investment of extra profits for the long-term) can help directly in generating social sustainability, for example, affordability and community cohesion aspects [4, 12], and creating 'green' environments. This is because economic sustainability, unlike the one-dimensional and short-sighted profit paradigm, operates on long time-horizons and multiple dimensions. The issue here is as to whether there are enough incentives to switch paradigms in such a way, which, as a result, would trigger the production of 'sustainable real estate' instead of 'conventional real estate' [13]. Secondly, social sustainability criteria can be met if localized quality-of-life (QOL) is invested in, insofar as we assume that happiness, affordability, functionality, sense of community and similar 'soft' considerations are the building blocks of a socially sustainable location $[4,12,14,15]$.

Furthermore let us assume here that long-term investments generate extra profits. The argument concerns how the extra profits reaped from long-term investments could be used to generate sustainability in other than economic terms too [16]. For example, the project developer invests in bus stops and in more green features. To get private developers interested in this requires long-term economic strategies from them [17]. This in turn requires good governance and designing apt institutions to direct the investments on the right track.

Fortunately it is increasingly recognised that sustainable property development and investment can give the corporation or firm a competitive advantage [13, 16, 18, 19]. This is furthermore bound to be reflected in the property value. However, for economic sustainability arguments to be taken on board by investors and developers as well as architects and regulators requires a steady and sustained price lift, and not only for the price levels set by the project but for the property values created in the surrounding area and adjacent neighbourhoods too [18]. In this way, prices and values of the dwellings and rents of office space contain powerful information for the purpose of deciding on an economically sustainable strategy. What complicates the picture is that property values and valuations have a double function as sustainability indicators: the property value in fact can be substantially increased by acknowledging sustainability in general and 'green' issues in particular, but that, unfortunately, it can also be increased by unsustainable elements as well (as will be shown in next section). While recent studies have managed to verify the hypothesis of sustainability elements commanding a premium at the marketplace [19-21], real estate economic analysis of sustainability $v i s-a$-vis price outcomes is yet in its infancy. 
In what follows a number of qualifications are proposed for evaluating the sustainability of property development related to the points 4 to 6 in the list above, as these three issues target the 'property product' rather than smaller or wider scales (building in the first three points; areas in the last six points). ${ }^{3}$ For the analytical purposes of this study the sustainability goal is decomposed as follows:

- As grossly substandard quality level of residential, office or retail space is unacceptable for health and safety reasons; this is also about the characteristics of the surrounding environment, neighborhood and the city as a whole.

- $\quad$ High quality alone is insufficient unless the unit is affordable for the residents or firms.

- Even if the quality and affordability criteria are fulfilled, it is insufficient unless there is a wide enough product variety generated for apt selections to be made from different quality and affordability levels on the market. This is because the drivers of sustainability (production technology, community governance, consumption fashions etc.) tend to change fast and then it is vital not to have neglected any specific package even if it may seem marginal at some stage.

Table 1 shows the connections between the concepts mentioned. 'Quality' and 'affordability' are easily accommodated within mainstream economics. Quality aspects are often dealt with using hedonic price models, whereas the affordability arguments are often dealt with using a welfare economics framework. The innovation here concerns the third of the concepts - 'differentiation' of the product range in order to allow for innovation in terms of quality or affordability, so as to accommodate an evolutionary perspective.

Table 1. The Connections Between the Three Sustainability Dimensions and Three Sustainability Criteria Applied in this Study

\begin{tabular}{|c|c|c|c|}
\hline & Environment & Economy & Social \\
\hline \hline Quality & $\mathrm{X}$ & & $\mathrm{X}$ \\
\hline Affordability & & $\mathrm{X}$ & $\mathrm{X}$ \\
\hline Differentiation & $\mathrm{X}$ & $\mathrm{X}$ & $\mathrm{X}$ \\
\hline
\end{tabular}

Sustainability items such as certified buildings are likely to benefit not only the tenant but also the landlord via reduction in operating costs, improved image and security of rent assuming a market situation where the occupants vote with their feet in search of optimal packages of costs and benefits, which in turn would mean less risk for the owner $[23,24]$. However, the opposite may be true: that despite the fact that the current state is found unsustainable, political changes will increase the uncertainty and thereby the risk

\footnotetext{
${ }^{3}$ Here it is to note that not everyone is so optimistic about the theoretical merits of the sustainability concept; for example, Greig [22] argues that sustainability has "lost its connection to holistic well-being and has become dominated by technocratic and economistic visions of society". Perhaps so, but it is too general an argument to debunk the setup of this particular study.
}

premium compared to a risk free 'current situation' [25]. According to this explanation, frequent political changes cause volatility, which further generates expectations of uncertainty, increases the investment risk and thereby also price premiums. Both views are logically deduced, but in the empirical material presented next this issue is left open.

\section{EVALUATION OF THE SUSTAINABILITY OF PROPERTY DEVELOPMENTS IN BUDAPEST}

Given the emerging debates about what sustainability in this context is (and what it is not), a case with grotesque differences along any dimension is advantageous. As will be shown, the Budapest case offers such circumstances. What follows is based on personal communication with the interviewed experts and comprises information about recent investment activity in the built environment. (It is to note that the majority of buildings that are old will not be discussed in detail.) The interviewees represented private investors, developers, builders and consultants as well as local government, NGO and academia. The questions concerned the motivations for selecting certain business strategies, achievability of different sustainability dimensions, expectations about property/land value increases, compatibility with the surrounding land use and neighbourhood characteristics, whether any marketing incentives were considered for the buyers and to what extent any cooperation with the municipality occurred. ${ }^{4}$

The starting point here is the massive privatization of the municipally owned (and formerly state owned) housing stock that occurred in the early 1990s [26, 27]. Subsequently Budapest councils used this privatization revenue as a reserve of funds for many regeneration projects during the late 1990s. This is not the case anymore. However, differences between districts in terms of building activity are still marked, as one of the interviewees pointed out (and see Table 2, over). For example district XIII have managed to do a number of projects such as to renovate and extend their new city hall, sports centers, community centers and healthcare facilities.

A literature on spatial differences in the physical deterioration of the building stock and socio-economic inequalities across Budapest emerged already in the 1990s $[26,28,29]$. This body of studies is however not explicitly dealing with sustainability. Some more recent studies in turn have managed to pick sustainability elements in relation to the upper market residential projects that occurred since end 1990 s $[1,30,31]$. In general in the aftermath of an ultra neoliberal period (2002-2010) endorsed by the previous government property developments of Budapest are mainly private driven; the era of public-private-partnership (PPP) based renewal of inner Budapest is over at least for the time being. Furthermore, as development of inner city sites has become financially unfeasible, the development activity has spread outside cities to former industrial areas, logistics centres, villages and Greenfield sites [32].

In Hungary data about building activity is available for the residential sector. It is collected through the census from

\footnotetext{
${ }^{4}$ To disclose all details about the exact method is not possible given the space allowed. However, here it needs to be noted that certain gate keepers (who are also listed among the respondents) managed to arrange access to the private developer respondents.
} 
Table 2. The Number of Dwellings Built in Each Budapest District 1995-2011

\begin{tabular}{|c|c|c|c|c|c|c|c|c|c|c|c|c|c|c|c|c|c|c|c|c|c|c|c|}
\hline Year & I & II & III & IV & V & VI & VII & VIII & IX & $\mathbf{X}$ & XI & XII & XIII & XIV & XV & XVI & XVII & XVIII & XIX & $\mathbf{X X}$ & XXI & XXII & XXIII \\
\hline 1995 & 74 & 34 & 79 & 131 & 54 & 4 & 0 & 68 & 88 & 25 & 197 & 87 & 54 & 545 & 60 & 470 & 229 & 336 & 50 & 60 & 64 & 201 & 44 \\
\hline 1996 & 0 & 403 & 71 & 112 & 7 & 7 & 1 & 7 & 177 & 45 & 154 & 245 & 22 & 280 & 83 & 216 & 199 & 405 & 54 & 98 & 72 & 147 & 69 \\
\hline 1997 & 27 & 372 & 186 & 119 & 3 & 4 & 28 & 0 & 254 & 79 & 328 & 194 & 8 & 354 & 163 & 183 & 219 & 211 & 43 & 152 & 59 & 164 & 61 \\
\hline 1998 & 61 & 420 & 305 & 262 & 8 & 0 & 7 & 5 & 137 & 18 & 235 & 171 & 85 & 288 & 76 & 127 & 143 & 174 & 49 & 93 & 65 & 162 & 54 \\
\hline 1999 & 28 & 405 & 182 & 159 & 58 & 0 & 16 & 8 & 98 & 51 & 261 & 185 & 50 & 505 & 50 & 143 & 129 & 201 & 56 & 68 & 64 & 129 & 58 \\
\hline 2000 & 39 & 343 & 243 & 185 & 25 & 17 & 17 & 33 & 225 & 42 & 94 & 192 & 233 & 524 & 93 & 145 & 98 & 183 & 39 & 103 & 54 & 145 & 41 \\
\hline 2001 & 55 & 519 & 555 & 359 & 17 & 5 & 44 & 84 & 504 & 90 & 168 & 176 & 134 & 650 & 223 & 77 & 129 & 237 & 98 & 66 & 66 & 106 & 72 \\
\hline 2002 & 1 & 494 & 895 & 755 & 13 & 51 & 54 & 247 & 653 & 35 & 150 & 139 & 427 & 725 & 585 & 139 & 80 & 517 & 44 & 82 & 119 & 141 & 127 \\
\hline 2003 & 22 & 214 & 351 & 568 & 28 & 31 & 49 & 199 & 625 & 90 & 401 & 72 & 803 & 929 & 184 & 176 & 96 & 761 & 66 & 474 & 22 & 88 & 64 \\
\hline 2004 & 43 & 218 & 885 & 590 & 17 & 43 & 204 & 512 & 987 & 451 & 296 & 193 & 2130 & 1354 & 237 & 169 & 348 & 722 & 91 & 273 & 216 & 121 & 52 \\
\hline 2005 & 7 & 43 & 532 & 982 & 25 & 269 & 434 & 259 & 1008 & 725 & 675 & 258 & 3250 & 1234 & 304 & 353 & 469 & 592 & 85 & 543 & 107 & 107 & 42 \\
\hline 2006 & 64 & 157 & 593 & 417 & 11 & 219 & 222 & 315 & 663 & 410 & 1297 & 149 & 898 & 775 & 136 & 170 & 400 & 490 & 195 & 288 & 178 & 146 & 46 \\
\hline 2007 & 5 & 162 & 268 & 623 & 35 & 73 & 273 & 331 & 1065 & 474 & 414 & 65 & 2516 & 1162 & 135 & 417 & 334 & 471 & 185 & 336 & 140 & 142 & 28 \\
\hline 2008 & 50 & 116 & 463 & 360 & 45 & 269 & 556 & 630 & 785 & 805 & 353 & 353 & 1115 & 661 & 209 & 375 & 613 & 985 & 50 & 141 & 84 & 309 & 150 \\
\hline 2009 & 39 & 239 & 477 & 356 & 23 & 296 & 374 & 719 & 602 & 729 & 1244 & 142 & 1091 & 844 & 161 & 377 & 504 & 1166 & 85 & 188 & 555 & 108 & 66 \\
\hline 2010 & 13 & 82 & 270 & 36 & 12 & 227 & 26 & 709 & 442 & 323 & 946 & 41 & 1178 & 517 & 90 & 257 & 131 & 260 & 83 & 332 & 49 & 112 & 50 \\
\hline 2011 & 14 & 94 & 223 & 122 & 7 & 75 & 81 & 829 & 252 & 39 & 238 & 23 & 177 & 351 & 35 & 158 & 119 & 67 & 58 & 58 & 61 & 83 & 28 \\
\hline
\end{tabular}

1995 onwards and managed by the National Statistical Office (KSH). Table 2 and APPENDIX 1 comprise a cursory overview of the house building in Budapest in recent years. The APPENDIX Tables (1a-c) provide information about the number and increase of dwellings; type of building; and form of financing, for selected districts. Table 2 and the APPENDICES show the diversity in building activity in Budapest across years, districts, property types and occupancy relations ${ }^{5}$. Here some examples that illustrate this variety can be given:

- Lots of building activity occurred during 2004 and 2005.

- Lots of activity took place in districts XIII and XIV.

- The annual increase in the dwelling stock over the seventeen year period varies between $0.4 \%$ and $1.9 \%$. The variation across districts is even greater: from nothing (e.g. district VIII in 1997) to almost ten per cent $(9.9 \%$, XIII, 2005).

- $\quad$ The most common property types are the detached (i.e. single-family) and multi-storey formats (i.e. condominiums). Residential parks, housing estates or row/terraced houses are built in considerably lesser volume.

- As for the occupancy relations and financing, most of the volume is built for sale. Private rental and public housing is built in lesser volumes.

Fig. (2) indicates the locations of the projects discussed in the text, including the two projects brought up in the

${ }^{5}$ The full info set is available from the author upon request. introduction (i.e. Marina Part and Vaskapu Street). It also shows the districts referred to in Table $\mathbf{2}$ and the APPENDIX Tables.

More than one of the private sector based interviewees underscore that, in general, due to the extremely global connections of the real estate industry developed after the transition, Budapest is more affected by crisis than other European cities. ${ }^{6}$ One of the problems here is that global planning and building trends tend to dominate the local ones. As long as the market situation is favorable the information about local circumstances is not transmitted to the developers. The solutions then remain standardised and not necessarily fit for a particular project. Thus, it is not then local solutions, but more often some kind of 'core sustainability' concepts that are applied trans-nationally in development projects. While the local governments are happy to attract the developers, the outcomes are however far from being sustainable (or even efficient) in such cases.

While the Hungarian type of gated community is not the sole topic of this study, this type of development has a special position in recent economic developments ${ }^{7}$. From the early 1990s privatization to the late 1990s upper-market lakópark developments, and the subsequent 'gold rush' (as one interviewee puts it), the lakópark functioned as a model for the masses [30]. Then the middle-class housing demand

\footnotetext{
${ }^{6}$ The value of property developments was 2 Billion EUR/year before 2008 and in 2009 only $50 \mathrm{M} /$ year!

${ }^{7}$ It is to observe that only c. $3.5 \%$ of the Budapest dwelling stock is of the residential park type. Since 2006, when KSH begun recording the volume of such projects, the yearly variation is considerable. For example, in 2010 as much as $24 \%$ of all dwellings built were of this type; in 2011 this figure was only $3.3 \%$.
} 


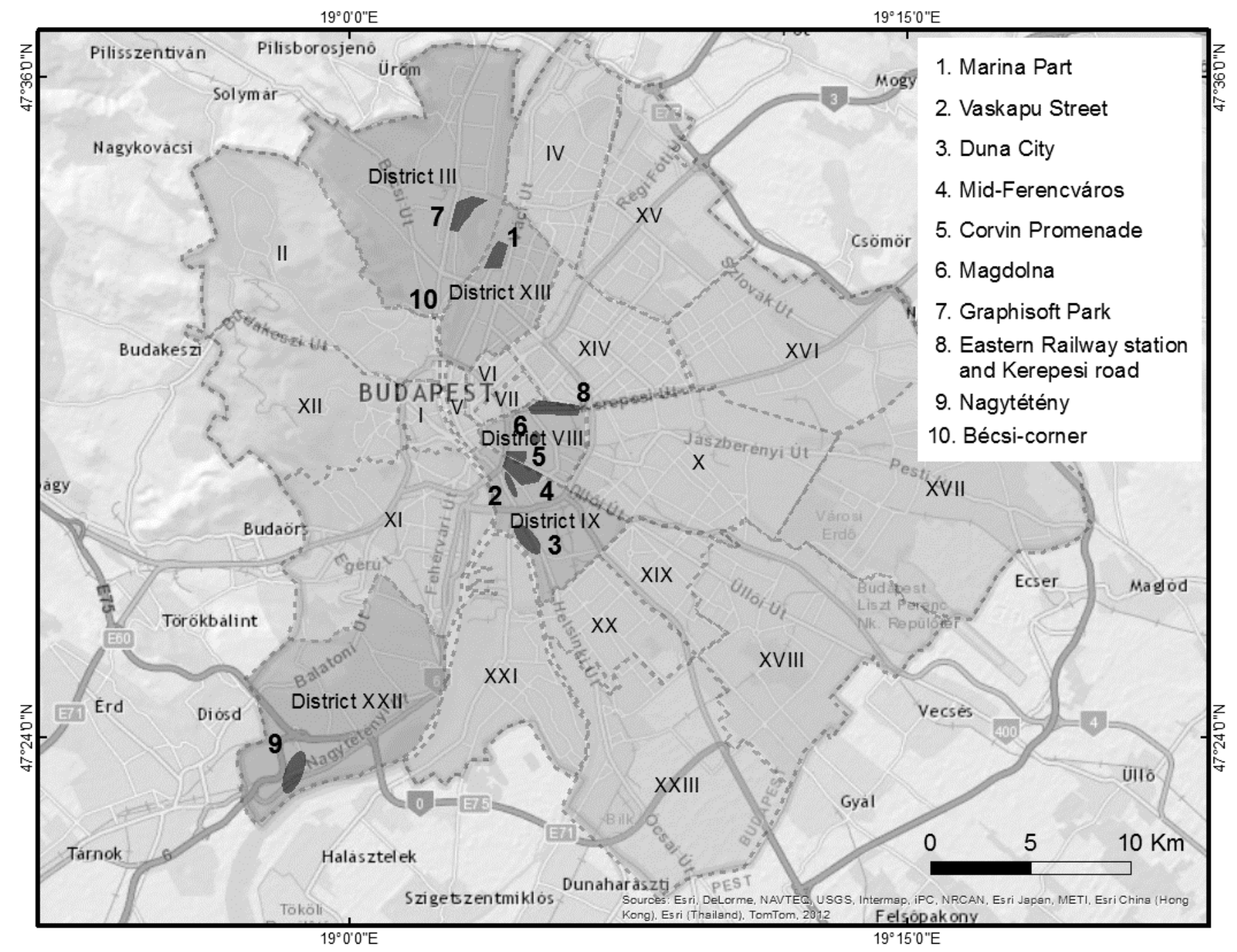

Fig. (2). Map of Budapest with all districts and the locations referred to in the text indicated. Source: http://www.openstreetmap.org/.

picked up this trend, with a strong increase in 2002-04, and a weaker increase after that until year 2008. This demand was fuelled by subsidies and by foreign-currency loans. The banks financed much of this 'gold rush' where both small and larger scale building entrepreneurs could utilise the opportunities provided. Then, finally after year 2007 this relationship between the banks and lakóparks ceased. Later, corrupt cases where local parties and businesses had built up an unregulated relationship of trust were revealed. While this property type is subject to plenty of critique, two sustainable features can be mentioned: first, because most gated communities were erected in urban transition zones the suburbanisation slowed down, and second, they were seen as a viable strategy for brownfield regeneration.

\section{Property Pricing}

In the Hungarian context of property value creation and price setting the following kinds of unsustainability problems exist:

(1) Lack of an 'unsustainability discount': In the residential sector and also elsewhere concerning the surroundings of the building there is no price reduction for the lack of sustainable elements. This is because somehow the market actors are sceptical or ignorant, which presumably is a consequence of the socialist past. However, as will be explained in next section, some promising tendencies are under way.

(2) Unrealistic price-setting by the seller in a consumers market (falling demand; oversupply). The lakóparks are almost completely seller-driven, which generates unsustainable tendencies in the price setting. ${ }^{8}$ The situation is similar in other types of property. The prevailing 'anything should go' mentality contradicts an establishment of buyer-driven frameworks that sustainability would require. Some of the interviews also suggested that, like in Western Europe, regardless of which sustainable features are included, the market downturn does not allow opportunities to reap premiums from which any improvements could be financed.

(3) Political issues: Changes in land ownership and land use involve myopic political and lobbying practices corruption too - that are extremely unsustainable in

${ }^{8}$ For the supply-driven process of establishing gated residential parks, see also [33] for a comparison of Budapest and Berlin. 
the long run. This is partly about actual changes and partly about 'the stroke of the pen'. This process comprises in fact a major planning problem in Hungary, especially when an election is approaching. The general strategy is as follows: someone buys agricultural land and then the politician, without carrying out any physical changes, redefines it as building land which is a far more valuable land use; then it is sold for many times its original price; finally, the seller returns a part of the profit to the political leader. The result of this sequence of events is not sustainable in any way.

As pointed out by two of the interviewees, yet another problem arises from the mismatch between the prices paid for land at the height of the boom and prices expected from the sales or leases of the completed floor-spaces. Regardless of potential value premiums stemming from the risk reduction for certified property, land values will not be realisable in those cases where the developer has bought sites during the market peak. In spring $201190 \%$ of office developments are on hold due to the crises, and many of them will not be continued until the years 2015-16. If interest costs have to be paid for the financing of the sites for that time period, reselling the site without considerable economic losses becomes difficult.

The problem types listed above can be seen as variations of the same theme of price increases bringing sustainable as well as unsustainable consequences. The first problem, the lack of price reduction for unsustainable elements in a project, could be solved with a validated price model (e.g. an estimated hedonic price equation) that penalises for such features. The second problem, the seller-driven agenda and overpricing of new developments regardless of sustainability considerations in turn is more difficult to solve as this would require a comprehensive upgrading of the existing building stock for urban and suburban areas alike towards the quality level of new buildings. As for the third problem, unsustainable politics and lobbying practices, this would require anti-corruption legislation [34]. For the fourth problem of too expensive site costs there is probably no solution. As the banks are hardly likely to give in, landowners have the options of panic sale or to wait - in both cases resulting in economic losses for years to come.

As one interviewee put it: "We expect that all sorts of things will increase the value - some of them are sustainable". Here it can be added that, unlike the previous government who uncritically embraced a neoliberal agenda, the new government (after the change in May 2010) has placed sustainability issues on the agenda, but these promises are nonetheless subdued by the prevailing market ignorance together with the deeply rooted unsustainable property and land speculation practices highlighted above. Furthermore, the common denominator mentioned by the private developer interviewees is that problems caused by political instability affect the business. This resonates with what was pointed out in the previous section: due to risk aversive actors the threat of institutional change can generate an unsustainable element.

\section{Land Use}

The formal planning system that existed before the year 1990 contained a distinction between 'framework' (ÁRT, metropolitan level comprehensive general zoning plan) and 'detailed' regulations (RRT, local level development plan). Informally this system stood until a change of planning law in 1997. Eventually, in the 1997 Act on the Formation and Protection of the Built Environment ÁRT and RRT were replaced by a structure plan (Településszerkezeti Terv, TSZT) covering whole cities and regulatory plans (Szabályozási Terv, SZT) for detailed zoning. The former is approved by a decision of the Municipal Council and does not give binding regulations; the latter is decided by a decree and thereby becomes local building legislation. However, one interviewee considers these changes in the Hungarian planning system insignificant in practice; even if new laws are established the problem is what 'legally binding' means for whom, why and how these documents are created. ${ }^{9}$ Moreover, sometimes laws remain ambiguous. If a developer, for instance, wants to build a big lakópark, then not only the regulatory plan, but the more general structure plan has to be modified. There is however no objective limit to be defined as to be such 'bigger' development volumes.

In the Hungarian planning system problems of inefficiency related to both the legitimacy of the planning system and the incompleteness of how existing laws and regulations are applied occurs in everyday practice [35]. Notably, the municipality can change the plans to accommodate new uses in case these do not fit the plan. This is often a relevant sequence of events in the case of multinational corporations and large scale 'bling' developments funded by institutional investors. Moreover, as a rule, developers attempt to change the plans to get more building rights, as one interviewee put it. In general for all projects, the zoning plan has to be rewritten in terms of building ratios and so forth, as more than one interviewee assured. Subsequently, the developer has to negotiate lengthy periods with both district (for the plot) and the city (when situated along a main road). This is seen clearly in the case of plans for mega projects such as Duna City (district IX, see Fig. 2).

\section{Neighbourhood Characteristics}

During the interviews, some of the benefits of the renewal projects in districts VIII (Corvin and Magdolna projects, see Fig. 2) and IX (mid-Ferencváros) received reasonable praise from academic, non government, public and private sector respondents alike, which even further strengthens the view of these two cases being - in relative terms - exceptionally well run projects $[36,37]$. The two districts are adjacent but different: district VIII being the most stigmatized area in the inner city and subject to revitalization efforts more recently; district IX being seen as a relative success story and a pioneer in urban renewal (Fig. 2). In these two districts the massive privatization of the housing stock that occurred in other inner city districts during the early $90 \mathrm{~s}$ was blocked - this was pointed out as a key issue in several interviews. The consensus of some of the interviews was that for sustainable urban renewal an

${ }^{9}$ For example, structure plans are sometimes modified too much due to serving developers' interests. 
active municipal strategy is vital and that only happened in these two districts - the others lacked such a vision. In particular, for district IX, at present, the completed parts look pleasant - traditional small-scale urban design with plenty of small green areas. The evaluation along the economic and environmental sustainability dimensions is here much more positive than in the neighbouring district VIII. However, for the social dimension, the evaluation seems the opposite, as the emphasis in the latter case much was on how to tackle social issues. In particular, in district VIII many of the original inhabitants could remain in the same district, unlike their counterparts in district IX who were offered alternative accommodation far away.

When evaluating the renewal of district VIII it should be noted that the differences between the two projects of this district are marked: Corvin (at the edge of the district, Fig. 2) being an on-going case of large-scale renewal and Magdolna (in the heart of this district, Fig. 2) representing a completed project aimed at merely developing the infrastructure such as a park and a community centre. To begin with, the financing of the two projects differs greatly:

- Corvin: Rév8 (the project management organisation funded by District VIII) first sold the land to a consortium of several developers; later a Hungarian managed (listed) property investment company Futureal bought all of it.

- $\quad$ Magdolna: Rév8, with EU funds.

The sustainability dimensions considered (at the outset) differ too:

- $\quad$ Corvin: Primarily social, but with economic elements too (e.g. an apartment hotel).

- Magdolna: Social and environmental.

As for the outcomes, the fit with the rest of the neighbourhood also differs:

- Corvin: Mixed results, but great expectations as the project is predicted to eventually revitalise a whole inner city neighbourhood.

- $\quad$ Magdolna: The environment did not change a lot. The only visible improvements concern a community centre, a pedestrian street and a small park.

On the office and retail side, the common problem is a neglect of any considerations about how the development fits with the rest of the neighbourhood. However, in some fortunate cases the developers did consider the surroundings, and threatened to "go elsewhere" unless the environment would improve. As one interviewee put it, "Hungary is catching up with the western countries on developer attitudes". On the other hand, another informant pointed out that, while many of the new developments are successful in terms of the environmental dimension, Greenfield constructions that take place at the periphery of metropolitan Budapest are problematic.

On the residential side, not even marginal social or economic sustainability aspects about how the new building(s) will fit into the surrounding environment are on the developers' agenda. Based on this evidence, residential parks are not sustainable with respect to environmental- ecological, social-cultural or economic-financial dimensions, as they often represent the latest 'bling' rather than profound 'green' solutions. Socially, in particular, they are often dubious, because they isolate the wealthy inhabitants of the area from the poor ones $[3,30]$. Economically they might offer functional diversity onto a supply driven market - thus in principle a sustainable aspect - but the market is already met in Budapest. There are also smaller private developments that do not belong to this category; these are ordinary condominiums without fenced areas.

As for the possibility of cooperation with the municipality (i.e. districts or metropolitan), especially the aforementioned Duna City project, which - despite being in complete standstill since the site was cleared - has included a fair share of sustainability planning such as green buildings, affordable housing and public transport infrastructure. However, many experts believe that this project might be unrealistic to complete. The few cases where government participated with the investments (notably the discussed Corvin promenade and the neighbouring midFerencváros renewal, Fig. 2) with the aim of improving plenty of the whole area (i.e. laying sewage, gas and pedestrian walk network) are given as compatible examples. More generally, to be successful, also in private projects there must be cooperation with both district and city government. However, unless being a PPP these do not participate in the funding, so the developer finances everything. This is well illustrated in the case of Graphisoft Park, a suburban large hi-tech office development in district III by the river Danube, where the municipality lacks funds to build the necessary traffic infrastructure (Fig. 2). Having an own car is assumed, which is unsustainable by definition and accentuated because of the poor road system and insufficient parking spaces.

As for the Budapest city core attractiveness, a number of changes look inevitable. Notably, at least two of the interviewees think that when the fourth metro-line is completed and, assuming the area around the Eastern railway station becomes 'nicer', it will be the new city centre and subsequently direct the development frontier (Fig. 2). This remains to be seen, but is not an unrealistic idea. The driving force for some investors here is the metro-station and developments along the adjacent main traffic artery (Kerepesi road), and this goes for commercial and residential functions alike. Of course it is acknowledged that the quality of the area can also go down (i.e. ghettoes spread), but this is considered a lesser risk.

\section{Summary of the Problems}

When summarising this case with respect to the three evaluation criteria, first and foremost, the quality of the locations in peripheral or suburban developments is rather poor. These developments are usually situated at the edges of traditional villages by motorway connections but without functional public transportation connections. The same can be said about many other services in the area. The infrastructure is still largely from socialist times whereas a mushrooming of residential parks and office and Hi-tech industrial parks has occurred from the mid 90s onwards. Even for centrally located projects, when actually completed, the quality of their surroundings is mostly substandard. 
Secondly, affordability of the packages on offer for investors as well as tenants (households and companies) is another general problem in a context where the middle class is very thin and persistent corruption practices are difficult to weed out. Here the poor timing of the investments leads to inevitable failure due to the harmful actions of land speculators and local politicians who add artificial elements to the land deals, or banks who charge high interest rates.

Thirdly, the standardized packages of new products do not appear to offer diversity on neither the commercial or residential side. To confirm this is difficult, however, as the evidence base of this study does not cover every on-going project. Besides, how the consumer tastes, political climates and technologies affect the demand structure is certainly impossible to predict, which is why options are best kept open. On the other hand, it was suggested that "not having much money around" forces one to be innovative and economical, which in turn can be translated into sustainability principles.

\section{LIGHT AT THE END OF THE TUNNEL}

In the previous section the problem of lack of discounts for unsustainable elements was brought up. However, some of the experts noted that a sustainability premium is increasingly being recognised for certain modern features of the building. Table 3 shows the findings from a nationwide survey undertaken by Farkas and colleagues [38] on how various aspects of energy efficiency of homes affect the selfassessed house value by owners. These results are based on a survey of homeowners where the property characteristics were recorded and the owners were asked to assess the value of their house. The survey was organized in 2003, and comprised 11,976 homes in 315 settlements of Hungary. These figures suggest that, because homebuyers have preferences for cheaper energy cost, they will increasingly choose a more expensive modern house (approximated by the variable 'boiler heating' in the survey) rather than a cheaper older one [32]. Moreover, when these choices of home buyers are accumulated over time and aggregated over the whole market area a subsequent switch towards greener housing stock is reality. Besides this, of academic interest is to note that in such a situation economically rational individual decisions also become correct from a sustainability point of view.

Table 3. The Impact of Energy Related Property Attributes on Per $\mathrm{m}^{2}$ Price

\begin{tabular}{|l|c|}
\hline Adobe masonry & $-13 \%$ \\
\hline Boiler heating & $+9 \%$ \\
\hline Prefabricated block of flats & $-8 \%$ \\
\hline Flat with room heating with coal, wood or electricity & $-14 \%$ \\
\hline The building needs insulation & $-4,5 \%$ \\
\hline District heating & $-4 \%$ \\
\hline Buildings with outdated heating system & $-3 \%$ \\
\hline Source: Farkas et al. [38]. &
\end{tabular}

Another tendency towards more sustainable development is identifiable when we consider the maintenance costs paid by homeowners in relation to the actual maintenance of common areas taking place in a residential building. This issue is about future quality premiums - also for the maintenance of the common areas: as noted earlier [2], due to the problems of the weak maintenance of the housing stock during the communist/socialist era and the early 90 s privatization of much of this stock, inner city condominiums are owned by a large share of poor people; in such cases the regulation of the condominium board is difficult. With individual ownership the owners' interests are scattered. In particular younger people are concerned about how to regulate this aspect of the condominiums. In a situation where two-thirds majority of the condominium board is required to make decisions about maintenance of common areas, all more modern condominium developments including the lakóparks then become a tempting alternative to the older type of condominium due to their clearer defined relationship between payments and services.

Thus, we note two potential drivers towards sustainable building stock: one is about energy issues and the other is about the regulation of condominiums. The interviews suggest that these promising tendencies have to do with the actions of a minority of innovative individuals who are able to understand long-term strategies. These actors, while possibly having learnt their trade abroad, have managed to distance themselves from the prevailing mentality and practices in this country. Here it should also be added that such relative success stories exist across the range of products on offer; even in individual large scale industrial development projects. One of them is the following positively surprising case (this interviewees happened to be a sustainability pioneer):

In the year 1997 the developer bought a Brownfield plot in Nagytétény at the southern outskirts of the Budapest district XXII (the approximate location is indicated in Fig. 2); this was based on a public tender. It was a former pig farm, in fact the biggest in CEE, which had gone bankrupt. It did not have pigs anymore, but had buildings. The concept was to redevelop the site to a warehouse base. The construction commenced in year 2000. In 2005 the completed project was sold to an institutional investor. The end product comprised 100,000 sqm of floorspace for $c$. twenty tenants including pharmacy, print shop and logistics service functions. The investor is believed to be happy as the end users are satisfied with the premises.

At the time no price premium existed for real estate sustainability. This project was among the first ones to incorporate such elements. Besides the fact that the site was on brownfield land, which is sustainable in itself, several more specific sustainability elements where included:

1. The site included two listed buildings, both of which were renovated.

2. The original foundations were reused in the building process.

3. Because the farm had not been connected to the off-site sewage network, the developer opted for making a completely new on-site sewage system. For this a separate sewage plant was built. This plant utilizes a wastewater treatment technology based on complex ecological engineering and process design.

4. Lots of cooperation with the municipality took place. 
Currently, sustainability is a serious fact when making the investment, even if not the most important factor. The difficulty in real estate business is to sell for profit and for that one needs to consider a variety of sustainability inducing features such as energy certificates, isolation, energy efficiency ratios and solar panels. One needs to try to imagine what the investor wants in five years time.

The good news is that the government has reintroduced forint-denominated state-subsidised home loans for year 2012. ${ }^{10}$ Apart from improving the market for condominiums, the policy is also designed to help in embarking on a more sustainable path of property development and also second hand market activity. The loan is available for new flats with price tags below HUF 30 million (c. 86,000 GBP) and for second hand flats with price tags below HUF 15 million (c. 43,000 GBP). The government also grants a social housing subsidy for households the size of which is based on the number of children in the family, the size of the flat and its energy efficiency qualification [39].

It is reason to keep in mind that these speculations do not cover the whole story of how to make the urban property developments more sustainable. Apart from the more site specific activities also a more comprehensive local development agenda is required. Here are yet several types of specific problems to solve, such as (1) the aptness and modernisation of the public transport system, (2) how to avoid ghettoization, homelessness and other socio-spatial problems, and (3) the political standards, that is to say, how to deal with corruption and fraud on one hand, and mere incompetence on the other. This is not to say that such problems do not occur in western circumstances.

\section{SUMMARY AND CONCLUSIONS}

The emerging literature on sustainable development mostly from western circumstances - strives to align environmental-ecologic, social-cultural and economic-financial dimensions. In this study such a model of sustainable urban property development was related to another partitioning in three such criteria: quality, affordability and diversity. If we confront this model with mainly qualitative findings from the Budapest circumstances, symptoms concerning quality (new versus old in particular) and affordability show up. Fortunately, amidst a currently weak housing and property (development) market - especially in terms of investment activity but also in terms of regulation efforts - some prospects exist. These open up mainly for niche developers that still manage to continue their projects viably such as Corvin Promenade (edge of district VIII) or Bécsi Corner (district III, Buda-side, see Fig. 2), but also more generally, a shift towards greater affordability and improved quality is likely in the long-term. However, the urban and neighbourhood level is rarely taken on board in these current development projects.

Thus we can conclude that the problems, since mid 2000s onwards, are inflicted by the mentioned 'gold rush' partially through mistakes made by the private developers and investors as well as individual owners, but also by the unfortunate economic trends that in themselves are the

\footnotetext{
${ }^{10}$ A generous mortgage subsidy system had been introduced in 1998/99 which led to a stimulated demand. This was subsequently abolished by the next government in 2003 .
}

aftermath of mistakes made by banks and local governments. The main problem here is an oversupply of new flats and offices due to the inapt locations chosen by the providers in many cases together with the wrong timing from the point of view of financing and saleability. The fact that the Hungarian middle class is rather thin should also be kept in mind here. Of these essentially economic problems then further social externalities emerge, and these in turn have further feedback effects that are capitalised on the economic side too. Finally, after year 2008 this Hungarian crisis then escalated as it became connected to the global downturn.

These circumstances indeed exemplify the arguments about sustainability involving elusive and contradictory concepts with varying achievability. Nonetheless, some speculation about a switch towards a greener building stock is possible, following encouraging recent evidence of sustainable property owner behaviour, notably the energy impacts of property attributes and the maintenance costs of common areas. These indications would suggest that, in the midst of the present obscurity surrounding the sustainability debate (even when we restrict us to global/western terms), it is not necessary that sustainable urban property development need strong planning, expropriation or other active public sector participation. It is not unreasonable to assume that a path towards sustainable urban property development can be arranged from a private sector base with contracts and apt management, instead of traditional planning based on government interventions. Incentives for private investors and developers are often considered a flexible option to steer the development towards a sustainable track. Much of the revitalising influence is already seen as the responsibility of a minority of visionary developers and investors, and also the average homebuyer here has a role to play. From a historical perspective it can be argued that private investment was always paramount for creating the great cities where ingenuity flourished in both civic and business arenas - one could spare a thought to late medieval Florence. Especially, in an impatient post-socialist context, imitating western European deliberative-democratic planning may not be the best solution.

\section{CONFLICT OF INTEREST}

The author confirms that this article content has no conflict of interest.

\section{ACKNOWLEDGEMENTS}

Earlier versions of the paper were presented at the "Real Estate Seminar" of Aalto University, Espoo, Finland, 7 April, 2011; and at the "Third ReCapNet Conference: Real Estate Markets and Capital Markets" of ZEW, Mannheim, Germany, October 14-15, 2011. I thank everyone who gave valuable comments at the mentioned academic events. I would also like to thank the interviewees (listed in APPENDIX 2), some of whom also supplied me with data without you this publication could not have materialized. I furthermore thank Radmil Popovic at our department for help in improving the map. A final word of gratitude and respect goes to the three anonymous referees, who took their time to give constructive feedback that undoubtedly helped me in improving the article to a publishable shape. 


\section{APPENDIX 1}

\section{DATA ON BUDAPEST HOUSING CONSTRUCTION IN SELECTED DISTRICTS 1995-2011}

Appendix Table 1a. Number and Increase of Dwellings in Selected Budapest Districts 1995-2011

\begin{tabular}{|c|c|c|c|c|}
\hline District & Year & The Dwelling Stock (Number) & Number of Dwellings Built & Percentage Increase of Dwellings in One Year \\
\hline \multirow{17}{*}{ III } & 1995 & 45078 & 179 & $0.40 \%$ \\
\hline & 1996 & 45466 & 171 & $0.38 \%$ \\
\hline & 1997 & 45782 & 186 & $0.41 \%$ \\
\hline & 1998 & 46185 & 305 & $0.66 \%$ \\
\hline & 1999 & 46566 & 182 & $0.39 \%$ \\
\hline & 2000 & $\mathrm{n} / \mathrm{a}$ & 243 & $\mathrm{n} / \mathrm{a}$ \\
\hline & 2001 & 46317 & 555 & $1.20 \%$ \\
\hline & 2002 & 46798 & 895 & $1.91 \%$ \\
\hline & 2003 & 47001 & 351 & $0.75 \%$ \\
\hline & 2004 & 47216 & 885 & $1.87 \%$ \\
\hline & 2005 & 47255 & 532 & $1.13 \%$ \\
\hline & 2006 & 47404 & 593 & $1.25 \%$ \\
\hline & 2007 & 47560 & 268 & $0.56 \%$ \\
\hline & 2008 & 47668 & 463 & $0.97 \%$ \\
\hline & 2009 & 47901 & 477 & $1.00 \%$ \\
\hline & 2010 & 47972 & 270 & $0.56 \%$ \\
\hline & 2011 & 48053 & 223 & $0.46 \%$ \\
\hline \multirow{17}{*}{ VIII } & 1995 & 35481 & 68 & $0.19 \%$ \\
\hline & 1996 & 35480 & 7 & $0.02 \%$ \\
\hline & 1997 & 35492 & 0 & $0.00 \%$ \\
\hline & 1998 & 35469 & 5 & $0.01 \%$ \\
\hline & 1999 & 35461 & 8 & $0.02 \%$ \\
\hline & 2000 & $\mathrm{n} / \mathrm{a}$ & 33 & $\mathrm{n} / \mathrm{a}$ \\
\hline & 2001 & 34922 & 84 & $0.24 \%$ \\
\hline & 2002 & 34960 & 247 & $0.71 \%$ \\
\hline & 2003 & 35006 & 199 & $0.57 \%$ \\
\hline & 2004 & 35208 & 512 & $1.45 \%$ \\
\hline & 2005 & 35642 & 259 & $0.73 \%$ \\
\hline & 2006 & 35766 & 315 & $0.88 \%$ \\
\hline & 2007 & 36039 & 331 & $0.92 \%$ \\
\hline & 2008 & 36577 & 630 & $1.72 \%$ \\
\hline & 2009 & 36918 & 719 & $1.95 \%$ \\
\hline & 2010 & 36944 & 709 & $1.92 \%$ \\
\hline & 2011 & 37024 & 829 & $2.24 \%$ \\
\hline \multirow{7}{*}{ IX } & 1995 & 40426 & 88 & $0.22 \%$ \\
\hline & 1996 & 40319 & 177 & $0.44 \%$ \\
\hline & 1997 & 40264 & 254 & $0.63 \%$ \\
\hline & 1998 & 40239 & 137 & $0.34 \%$ \\
\hline & 1999 & 40086 & 98 & $0.24 \%$ \\
\hline & 2000 & $\mathrm{n} / \mathrm{a}$ & 225 & $\mathrm{n} / \mathrm{a}$ \\
\hline & 2001 & 39939 & 504 & $1.26 \%$ \\
\hline
\end{tabular}




\begin{tabular}{|c|c|c|c|c|}
\hline District & Year & The Dwelling Stock (Number) & Number of Dwellings Built & Percentage Increase of Dwellings in One Year \\
\hline & 2002 & 40113 & 653 & $1.63 \%$ \\
\hline & 2003 & 40287 & 625 & $1.55 \%$ \\
\hline & 2004 & 40727 & 987 & $2.42 \%$ \\
\hline & 2005 & 40944 & 1008 & $2.46 \%$ \\
\hline & 2006 & 40966 & 663 & $1.62 \%$ \\
\hline & 2007 & 41207 & 1065 & $2.58 \%$ \\
\hline & 2008 & 41816 & 785 & $1.88 \%$ \\
\hline & 2009 & 42181 & 602 & $1.43 \%$ \\
\hline & 2010 & 42854 & 442 & $1.03 \%$ \\
\hline & 2011 & 43654 & 252 & $0.58 \%$ \\
\hline \multirow{17}{*}{ XIII } & 1995 & 32751 & 54 & $0.16 \%$ \\
\hline & 1996 & 32965 & 22 & $0.07 \%$ \\
\hline & 1997 & 33097 & 8 & $0.02 \%$ \\
\hline & 1998 & 33229 & 85 & $0.26 \%$ \\
\hline & 1999 & 33387 & 50 & $0.15 \%$ \\
\hline & 2000 & $\mathrm{n} / \mathrm{a}$ & 233 & $\mathrm{n} / \mathrm{a}$ \\
\hline & 2001 & 32425 & 134 & $0.41 \%$ \\
\hline & 2002 & 32557 & 427 & $1.31 \%$ \\
\hline & 2003 & 32619 & 803 & $2.46 \%$ \\
\hline & 2004 & 32794 & 2130 & $6.50 \%$ \\
\hline & 2005 & 33006 & 3250 & $9.85 \%$ \\
\hline & 2006 & 33119 & 898 & $2.71 \%$ \\
\hline & 2007 & 33170 & 2516 & $7.59 \%$ \\
\hline & 2008 & 33468 & 1115 & $3.33 \%$ \\
\hline & 2009 & 33487 & 1091 & $3.26 \%$ \\
\hline & 2010 & 33515 & 1178 & $3.51 \%$ \\
\hline & 2011 & 33532 & 177 & $0.53 \%$ \\
\hline \multirow{17}{*}{ XXII } & 1995 & 32096 & 201 & $0.63 \%$ \\
\hline & 1996 & 32144 & 147 & $0.46 \%$ \\
\hline & 1997 & 32174 & 164 & $0.51 \%$ \\
\hline & 1998 & 32234 & 162 & $0.50 \%$ \\
\hline & 1999 & 32269 & 129 & $0.40 \%$ \\
\hline & 2000 & $\mathrm{n} / \mathrm{a}$ & 145 & $\mathrm{n} / \mathrm{a}$ \\
\hline & 2001 & 32094 & 106 & $0.33 \%$ \\
\hline & 2002 & 32204 & 141 & $0.44 \%$ \\
\hline & 2003 & 32222 & 88 & $0.27 \%$ \\
\hline & 2004 & 32411 & 121 & $0.37 \%$ \\
\hline & 2005 & 32501 & 107 & $0.33 \%$ \\
\hline & 2006 & 32542 & 146 & $0.45 \%$ \\
\hline & 2007 & 32588 & 142 & $0.44 \%$ \\
\hline & 2008 & 32634 & 309 & $0.95 \%$ \\
\hline & 2009 & 33064 & 108 & $0.33 \%$ \\
\hline & 2010 & 33107 & 112 & $0.34 \%$ \\
\hline & 2011 & 33157 & 83 & $0.25 \%$ \\
\hline
\end{tabular}


Appendix Table 1b. Number of Different Types of Dwellings Built in Selected Budapest Districts 1995-2011

\begin{tabular}{|c|c|c|c|c|c|c|c|}
\hline District & Year & $\begin{array}{c}\text { Number of } \\
\text { Dwellings Built }\end{array}$ & $\begin{array}{c}\text { Number of } \\
\text { Dwellings Built in } \\
\text { the Form of } \\
\text { Detached Houses }\end{array}$ & $\begin{array}{c}\text { Number of } \\
\text { Dwellings Built in } \\
\text { the Form of Housing } \\
\text { Estates }\end{array}$ & $\begin{array}{c}\text { Number of } \\
\text { Dwellings Built in } \\
\text { the Form of Multi- } \\
\text { Storey, Multi- } \\
\text { Dwelling Buildings }\end{array}$ & $\begin{array}{c}\text { Number of } \\
\text { Dwellings Built in } \\
\text { the Form of Row or } \\
\text { Terraced Houses }\end{array}$ & $\begin{array}{c}\text { Number of } \\
\text { Dwellings Built in } \\
\text { the Form of } \\
\text { 'Residential Parks' }\end{array}$ \\
\hline \multirow{17}{*}{ III } & 1995 & 179 & 95 & 0 & 30 & 23 & $\mathrm{n} / \mathrm{a}$ \\
\hline & 1996 & 171 & 101 & 0 & 27 & 20 & $\mathrm{n} / \mathrm{a}$ \\
\hline & 1997 & 186 & 136 & 1 & 14 & 7 & $\mathrm{n} / \mathrm{a}$ \\
\hline & 1998 & 305 & 140 & 0 & 74 & 65 & $\mathrm{n} / \mathrm{a}$ \\
\hline & 1999 & 182 & 137 & 0 & 35 & 10 & $\mathrm{n} / \mathrm{a}$ \\
\hline & 2000 & 243 & 137 & 0 & 85 & 21 & $\mathrm{n} / \mathrm{a}$ \\
\hline & 2001 & 555 & 182 & 1 & 343 & 29 & $\mathrm{n} / \mathrm{a}$ \\
\hline & 2002 & 895 & 177 & 86 & 581 & 51 & $\mathrm{n} / \mathrm{a}$ \\
\hline & 2003 & 351 & 128 & 1 & 214 & 4 & $\mathrm{n} / \mathrm{a}$ \\
\hline & 2004 & 885 & 134 & 1 & 595 & 0 & $\mathrm{n} / \mathrm{a}$ \\
\hline & 2005 & 532 & 91 & 0 & 310 & 0 & $\mathrm{n} / \mathrm{a}$ \\
\hline & 2006 & 593 & 81 & 0 & 361 & 2 & 149 \\
\hline & 2007 & 268 & 89 & 0 & 141 & 8 & 30 \\
\hline & 2008 & 463 & 69 & 0 & 341 & 4 & 49 \\
\hline & 2009 & 477 & 87 & 0 & 323 & 18 & 49 \\
\hline & 2010 & 270 & 65 & 0 & 189 & 16 & 0 \\
\hline & 2011 & 223 & 52 & 0 & 83 & 2 & 86 \\
\hline \multirow{17}{*}{ VIII } & 1995 & 68 & 0 & 0 & 56 & 0 & $\mathrm{n} / \mathrm{a}$ \\
\hline & 1996 & 7 & 0 & 0 & 0 & 0 & $\mathrm{n} / \mathrm{a}$ \\
\hline & 1997 & 0 & 0 & 0 & 0 & 0 & $\mathrm{n} / \mathrm{a}$ \\
\hline & 1998 & 5 & 0 & 0 & 0 & 0 & $\mathrm{n} / \mathrm{a}$ \\
\hline & 1999 & 8 & 0 & 0 & 8 & 0 & $\mathrm{n} / \mathrm{a}$ \\
\hline & 2000 & 33 & 1 & 0 & 30 & 2 & $\mathrm{n} / \mathrm{a}$ \\
\hline & 2001 & 84 & 4 & 0 & 80 & 0 & $\mathrm{n} / \mathrm{a}$ \\
\hline & 2002 & 247 & 0 & 0 & 247 & 0 & $\mathrm{n} / \mathrm{a}$ \\
\hline & 2003 & 199 & 1 & 50 & 143 & 4 & $\mathrm{n} / \mathrm{a}$ \\
\hline & 2004 & 512 & 1 & 0 & 391 & 0 & $\mathrm{n} / \mathrm{a}$ \\
\hline & 2005 & 259 & 0 & 0 & 259 & 0 & $\mathrm{n} / \mathrm{a}$ \\
\hline & 2006 & 315 & 0 & 0 & 315 & 0 & 0 \\
\hline & 2007 & 331 & 0 & 0 & 331 & 0 & 0 \\
\hline & 2008 & 630 & 0 & 0 & 630 & 0 & 0 \\
\hline & 2009 & 719 & 0 & 0 & 719 & 0 & 0 \\
\hline & 2010 & 709 & 2 & 0 & 707 & 0 & 0 \\
\hline & 2011 & 829 & 0 & 1 & 828 & 0 & 0 \\
\hline \multirow{3}{*}{ IX } & 1995 & 88 & 0 & 0 & 84 & 0 & $\mathrm{n} / \mathrm{a}$ \\
\hline & 1996 & 177 & 0 & 0 & 80 & 0 & $\mathrm{n} / \mathrm{a}$ \\
\hline & 1997 & 254 & 0 & 0 & 234 & 0 & $\mathrm{n} / \mathrm{a}$ \\
\hline
\end{tabular}




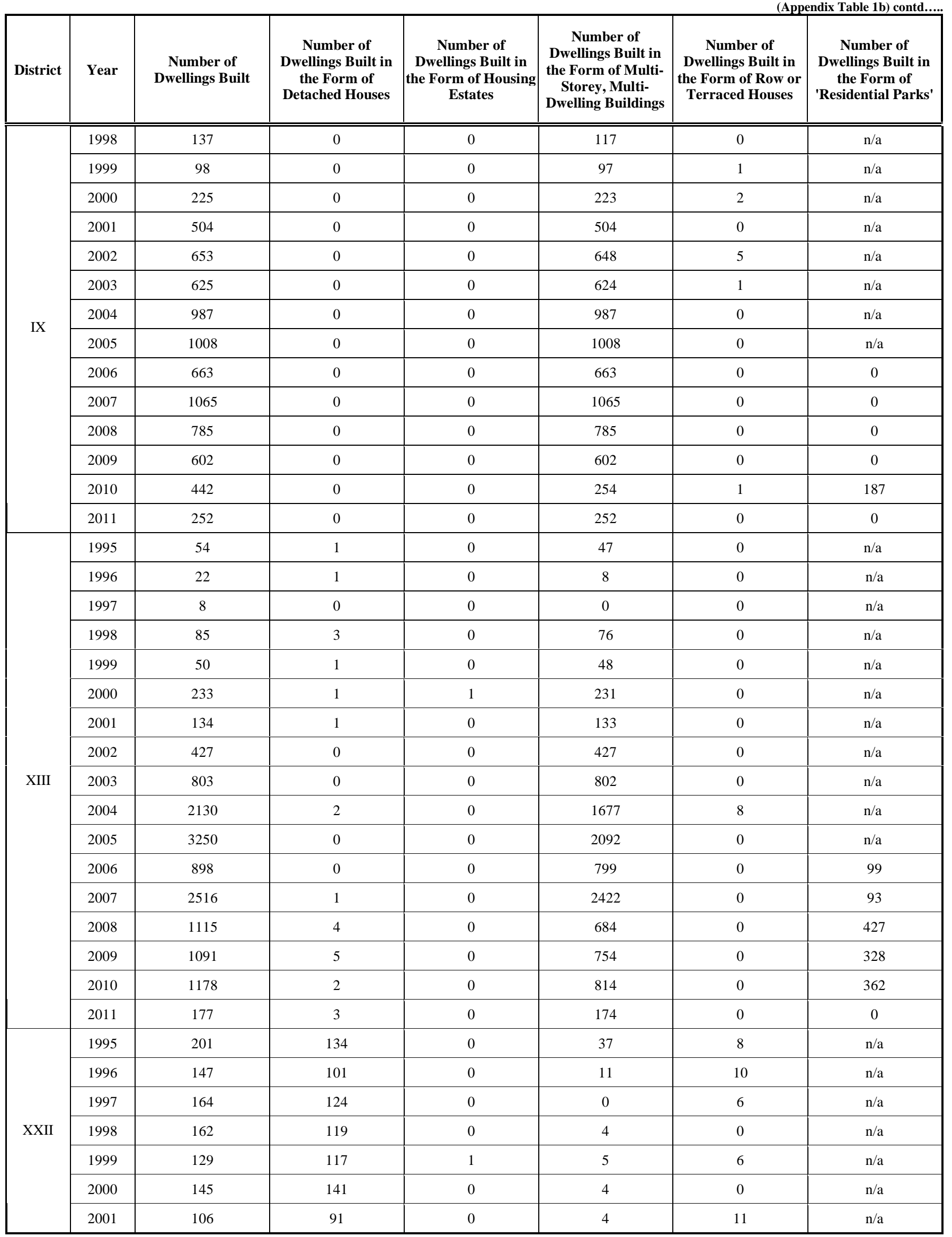


(Appendix Table 1b) contd.....

\begin{tabular}{|c|c|c|c|c|c|c|c|}
\hline District & Year & $\begin{array}{c}\text { Number of } \\
\text { Dwellings Built }\end{array}$ & $\begin{array}{c}\text { Number of } \\
\text { Dwellings Built in } \\
\text { the Form of } \\
\text { Detached Houses }\end{array}$ & $\begin{array}{c}\text { Number of } \\
\text { Dwellings Built in } \\
\text { the Form of Housing } \\
\text { Estates }\end{array}$ & $\begin{array}{c}\text { Number of } \\
\text { Dwellings Built in } \\
\text { the Form of Multi- } \\
\text { Storey, Multi- } \\
\text { Dwelling Buildings }\end{array}$ & $\begin{array}{c}\text { Number of } \\
\text { Dwellings Built in } \\
\text { the Form of Row or } \\
\text { Terraced Houses }\end{array}$ & $\begin{array}{c}\text { Number of } \\
\text { Dwellings Built in } \\
\text { the Form of } \\
\text { 'Residential Parks' }\end{array}$ \\
\hline \multirow{10}{*}{ XXII } & 2002 & 141 & 100 & 0 & 4 & 36 & $\mathrm{n} / \mathrm{a}$ \\
\hline & 2003 & 88 & 71 & 0 & 0 & 15 & $\mathrm{n} / \mathrm{a}$ \\
\hline & 2004 & 121 & 69 & 0 & 37 & 15 & $\mathrm{n} / \mathrm{a}$ \\
\hline & 2005 & 107 & 69 & 0 & 26 & 12 & $\mathrm{n} / \mathrm{a}$ \\
\hline & 2006 & 146 & 75 & 4 & 58 & 9 & 0 \\
\hline & 2007 & 142 & 73 & 0 & 50 & 7 & 12 \\
\hline & 2008 & 309 & 40 & 2 & 153 & 0 & 114 \\
\hline & 2009 & 108 & 76 & 0 & 23 & 9 & 0 \\
\hline & 2010 & 112 & 61 & 0 & 36 & 13 & 2 \\
\hline & 2011 & 83 & 70 & 0 & 13 & 0 & 0 \\
\hline
\end{tabular}

Appendix Table 1c. Number of Dwellings with Different Financing/Ownership Status Built in Selected Budapest Districts 19952011

\begin{tabular}{|c|c|c|c|c|}
\hline District & Year & Number of Dwellings Built for Sale & Number of Dwellings Built for Rental & Number of Dwellings Built by Local or Central Government \\
\hline \multirow{17}{*}{ III } & 1995 & 29 & 0 & 0 \\
\hline & 1996 & 33 & 0 & 0 \\
\hline & 1997 & 14 & 0 & 0 \\
\hline & 1998 & 83 & 0 & 0 \\
\hline & 1999 & 34 & 0 & 0 \\
\hline & 2000 & 72 & 0 & 0 \\
\hline & 2001 & 316 & 0 & 4 \\
\hline & 2002 & 701 & 0 & 0 \\
\hline & 2003 & 208 & 0 & 8 \\
\hline & 2004 & 705 & 0 & 0 \\
\hline & 2005 & 419 & 0 & 0 \\
\hline & 2006 & 470 & 0 & 0 \\
\hline & 2007 & 161 & 2 & 0 \\
\hline & 2008 & 387 & 0 & 0 \\
\hline & 2009 & 273 & 1 & 0 \\
\hline & 2010 & 181 & 0 & 0 \\
\hline & 2011 & 167 & 1 & 0 \\
\hline \multirow{7}{*}{ VIII } & 1995 & 56 & 0 & 0 \\
\hline & 1996 & 0 & 0 & 0 \\
\hline & 1997 & 0 & 0 & 0 \\
\hline & 1998 & 0 & 3 & 3 \\
\hline & 1999 & 0 & 0 & 0 \\
\hline & 2000 & 0 & 8 & 0 \\
\hline & 2001 & 46 & 7 & 0 \\
\hline
\end{tabular}




\begin{tabular}{|c|c|c|c|c|}
\hline District & Year & Number of Dwellings Built for Sale & Number of Dwellings Built for Rental & Number of Dwellings Built by Local or Central Government \\
\hline & 2002 & 227 & 2 & 0 \\
\hline & 2003 & 73 & 4 & 51 \\
\hline & 2004 & 377 & 2 & 122 \\
\hline & 2005 & 250 & 0 & 0 \\
\hline & 2006 & 305 & 0 & 0 \\
\hline & 2007 & 327 & 0 & 0 \\
\hline & 2008 & 618 & 0 & 0 \\
\hline & 2009 & 716 & 1 & 0 \\
\hline & 2010 & 705 & 0 & 0 \\
\hline & 2011 & 828 & 0 & 0 \\
\hline \multirow{17}{*}{ IX } & 1995 & 84 & 0 & 0 \\
\hline & 1996 & 94 & 55 & 55 \\
\hline & 1997 & 234 & 0 & 0 \\
\hline & 1998 & 117 & 0 & 0 \\
\hline & 1999 & 74 & 0 & 34 \\
\hline & 2000 & 173 & 32 & 32 \\
\hline & 2001 & 489 & 0 & 0 \\
\hline & 2002 & 624 & 0 & 21 \\
\hline & 2003 & 619 & 1 & 1 \\
\hline & 2004 & 960 & 0 & 0 \\
\hline & 2005 & 975 & 0 & 0 \\
\hline & 2006 & 658 & 0 & 0 \\
\hline & 2007 & 1059 & 0 & 0 \\
\hline & 2008 & 728 & 55 & 0 \\
\hline & 2009 & 438 & 162 & 77 \\
\hline & 2010 & 411 & 30 & 30 \\
\hline & 2011 & 154 & 98 & 98 \\
\hline \multirow{13}{*}{ XIII } & 1995 & 41 & 0 & 0 \\
\hline & 1996 & 8 & 0 & 0 \\
\hline & 1997 & 0 & 0 & 0 \\
\hline & 1998 & 77 & 0 & 0 \\
\hline & 1999 & 46 & 0 & 0 \\
\hline & 2000 & 231 & 0 & 0 \\
\hline & 2001 & 131 & 0 & 0 \\
\hline & 2002 & 333 & 94 & 94 \\
\hline & 2003 & 736 & 42 & 0 \\
\hline & 2004 & 2126 & 0 & 0 \\
\hline & 2005 & 3113 & 137 & 61 \\
\hline & 2006 & 883 & 0 & 0 \\
\hline & 2007 & 2515 & 0 & 0 \\
\hline
\end{tabular}




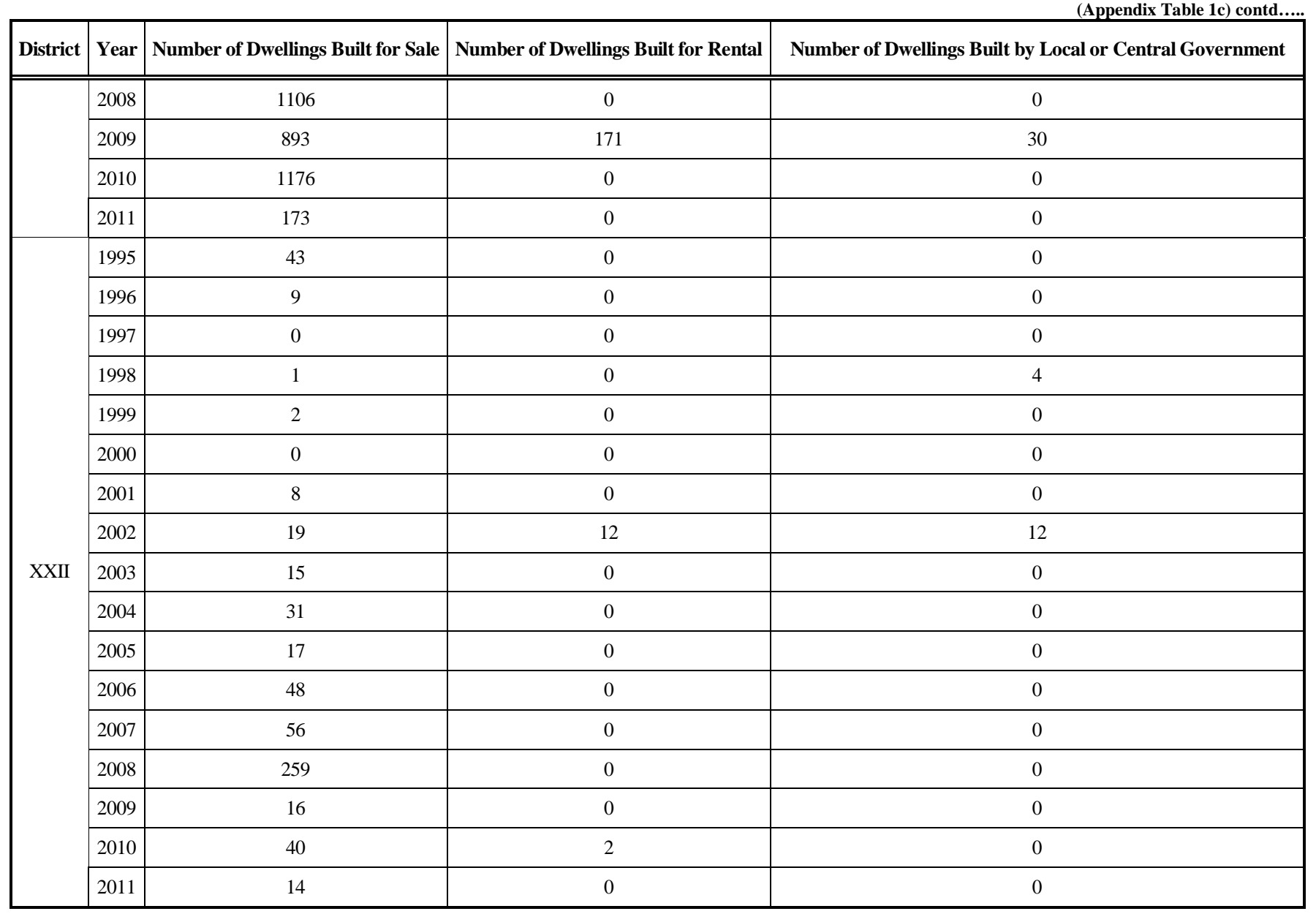

\section{APPENDIX 2}

\section{INTERVIEWS}

Anonymous, Lecturer, University of Szeged, discussions 14 October 2009 and 30 December 2009; emailing correspondence 18 January 2010, 11 March 2010, 6 April 2011, 29 April 2011 and 8 May, 2011.

Anonymous, Planner based in Kecskemét, discussion 15 November 2010.

Gábor Balás, managing director of HETFA Research Institute (with colleague, managing director András Csite), discussion 26 September, 2011.

Bálint Csatári, Director, Alföld Institute, Centre for Regional Studies, Hungarian Academy of Sciences, discussions 15 and 16 November, 2010; email correspondence 4 and 10 November, and 20 December.

Zsuzsanna Földi (with colleagues), Head of Research, MTA RKK, 20 December 2010.

István Hajnal, CEO of Biggeorges-NV Real Estate Development, 29 March, 2011.

Áron Horváth, Head of ELTINGA (with colleague, Miklós Farkas) 4 February, 2011.

Miklós Jakab, Director, Valuation \& Consultancy, GVA Robertson, 25 March, 2011.
Ákos Jakobi, Lecturer, ELTE, discussion 28 September, 2009.

Péter Jordán, General Manager, SEM IX Városfejlsztő Zrt, discussion 18 May, 2011.

Zsolt Kákosy, Managing director, SAM-LAK KFt, Member of Raiffeisen Property Holding International (RPHI) group, discussion 28 September, 2011.

Krisztián Karácsony, Managing Director, ECORYS Hungary, discussion 17 December 2009.

Gábor Locsmándi, Professor, Budapest University of Technology and Economics, discussion January 2005.

György Molnár, Senior Research Fellow, Institute of Economics, Hungarian Academy of Sciences, and Expert, local government of district VIII, discussion 18 May, 2011.

Gábor Péter, Volumetric, discussion 28 March, 2011.

Péter Rapkay, procurist, sales manager, CFE Hungary Kft, discussion 30 March, 2011.

Gábor Soóki-Tóth, Manager, CBS Property Zrt, discussions 5 January and 7 October, 2011; emailing correspondence 27 January 2010, 6 April, 2011 and 11 October 2011.

Kyra Tomay, Planner-analyst, Department of Spatial Policy, International and Urban Affairs Spatial Planning and Evaluation Directorate, VÁTI Hungarian Public Nonprofit Company for Regional Development and Town Planning, discussion 9 March, 2011. 

2009.

Dávid Valkó, Otthon Centrum, discussion 29 September

\section{REFERENCES}

[1] Kulcsar LJ, Domokos T. The Post-Socialist Growth Machine: The Case of Hungary. Int J Urban Reg Res 2005; 29(3): 550-63.

[2] Stanilov K, 'The challenges facing Eastern and Central European cities in the beginning of the 21th century', paper presented at the symposium "GIS Ostrava 2013 - Geoinformatics for City Transformation", January $21-23$, Ostrava 2013.

[3] Csanádi G, Csizmady A, Olt G. Recent trends in urban renewal in Budapest. Urbani Izziv 2010; 21(1): 117-25.

[4] Manzi T, Lucas K, Lloyd-Jones T, Allen J. Understanding Social Sustainability: Key Concepts and Developments in Theory and Practice. In: Manzi T, Lucas K, Lloyd-Jones T, Allen J, Eds. Social Sustainability in Urban Areas. Communities, Connectivity and the Urban Fabric, London and Washington DC: Earthscan 2010; pp. 128.

[5] LUDEN. Towards a new paradigm for Local Urban Development. 2012. Available at http://qeceran.cluster003.ovh.net/documents/To wards-a-new-paradigm-for-Local-Urban-Development.pdf [Accessed 24 November, 2012].

[6] Wagner A, Gossauer E, Moosmann C, Gropp Th, Leonhart R. Thermal comfort and workplace occupant satisfaction - results of field studies in German low energy office build. Energy Build 2007; 39: 758-69.

[7] Silhankova V, Koutny J, Mastalka M, et al. Indicators of Sustainable Development for Municipalities. Hradec Králové: Civitas per Populi 2011.

[8] Ellison L, Sayce S, Smith J. Socially Responsible Property Investment: Quantifying the Relationship between Sustainability and Investment Property Worth. J Prop Res 2007; 24(3): 191-219.

[9] Jones C, Watkins C. Urban Regeneration and Sustainable Markets. Urban Stud 1996; 33(7): 1129-40.

[10] Jones C, Leishman C, MacDonald C. Sustainable urban form and residential development viability. Environ Plan A 2009; 41(7): 1667-90.

[11] Kauko T. Sustainable urban property development and neighbourhood dynamics, 'mini-review. Open Urban Stud J 2010; 3: 103-11.

[12] Bramley G, Dempsey N, Power S, Brown C, Watkins D. Social sustainability and urban form: evidence from five British cities. Environ Plan A 2009; 41: 2125-42.

[13] Prince's Foundation. Delivering Sustainable Urbanism, SLIM - A Strategic Land Investment Model. The Prince's Foundation for the Built Environment 2010.

[14] Bramley G, Power S. Urban form and social sustainability: the role of density and housing type. Environ Plan B Plan Des 2009; 36(9): 30-48.

[15] Csanádi G, Csizmady A, Olt G. Social sustainability and urban renewal. On the example of inner-Erzsébetváros in Budapest. Soc Econ 2011; 33(1): 199-17.

[16] Bryson JR, Lombardi R. Balancing Product and Process Sustainability against Business Profitability: Sustainability as a Competitive Strategy in the Property Development Process. Bus Strategy Environ 2009; 18(2): 97-107.

[17] Cooper J, Ryley T, Smyth A, Alayo J. The interaction between consumer response and urban design: empirical results from Belfast. Environ Plan A 2001; 33: 1265-78.

[18] Lützkendorf Th, Fan W, Lorenz D. Engaging financial stakeholders: opportunities for a sustainable built environment. Build Res Inf 2011; 39(5): 483-503.
[19] Eichholz P, Kok N, Quigley J. Doing Well by Doing Good? Green Office Buildings. Am Econ Rev 2010; 100: 2492-509.

[20] Deng Y, Li Zh, Quigley JM. Economic Returns to Energy-Efficient Investments in the Housing Market: Evidence from Singapore. IRES Working Paper Series, August 2010 (IRES2010-008).

[21] Yu Sh-M, Tu Y. Are Green Buildings worth more because they cost more? IRES Working Paper Series, August 2011 (IRES2011023).

[22] Greig A. Shoe-horning the 'Sustainable' into Urban Regeneration. Reg Insights 2010; 14

[23] Eichholz P, Kok N, Quigley J. Why Do Companies Rent Green? Real Property and Corporate Social Responsibility. London: RICS Research 2009.

[24] Fuerst F, McAllister P. Green Noise or Green Value? Measuring the Effects of Environmental Certification on Office Values. Real Estate Econ 2011; 39(1): 45-69.

[25] Tu Y, Bao HXH. Property Rights and Housing Value: The Impacts of Political Stability. Real Estate Econ 2009; 37(2): 235-57.

[26] Kovács Z. Ghettoization or gentrification? Post-socialist scenarios for Budapest. Netherlands J Hous Built Environ 1998; 13(1): 6382.

[27] Kovács Z, Wiessner R. Budapest - Restructuring a European Metropolis. Eur Reg 2004; 12(1): 22-31.

[28] Ladányi J. Patterns of Residential Segregation and the Gypsy Minority in Budapest. Int J Urban Reg Res 1993; 17(1): 30-41.

[29] Hegedüs J, Mark K, Struyk R, Tosics I. Tenant Satisfaction with Public Housing Management: Budapest in Transition. Hous Stud 1994; 9(3): 315-28.

[30] Kulcsar LJ, Domokos T. The Post-Socialist Growth Machine: The Case of Hungary. Int J Urban Reg Res 2005; 29(3): 550-63.

[31] Csizmady A, Csanádi G. Gated Communities versus Large Housing Estates. Unpublished manuscript 2009; Available at: www.soc.cas.cz/.../887/paper_csizmady_w18.pd [Accessed 24 November, 2012].

[32] Cséfalvay Z. Searching for Economic Rationale behind Gated Communities: A Public Choice Approach. Urban Stud 2011; 48(4): 749-64.

[33] Kauko T. End in sight? On the (un) sustainability of property development in the Budapest region. Int J Strategic Prop Manag 2012; 16(1): 37-55.

[34] Bodnár J, Molnár V. Reconfiguring Private and Public: State, Capital and New Housing Developments in Berlin and Budapest. Urban Stud 2010; 47(4): 789-812.

[35] Kauko T. Planning processes, development potential and house prices: contesting positive and normative argumentation. Hous Theory Soc 2003; 20(3): 113-26.

[36] Locsmándi G, Péteri G,Varga-Ötvös B. Urban Planning and Capital Investment Financing in Hungary. Budapest: Local Government and Public Service Reform Initiative. Open Society Institute 2000.

[37] Kauko T. Urban housing patterns in a tide of change: Spatial structure and residential property values in Budapest in a comparative perspective. Delft: DUP Science Publication 2006.

[38] Kauko T. The housing market dynamics of two Budapest neighbourhoods. Hous Stud 2009; 24(5): 587-10.

[39] Farkas J, Giczi J, Székely G. Housing Conditions 1999-2003, Hungarian Central Statistical Office 2004; Available at http://mek.oszk.hu/06900/06979/06979.pdf [Accessed 22 September 2011].

[40] Portfolio.hu, Available at http://www.portfolio.hu/en/economy/hun gary_restores_social_housing_subsidy.23080.html [Accessed 18 October, 2011]. 